\title{
Toxicological, enzymatic, and immunochemical characterization of Bothrops asper (Serpentes: Viperidae) reference venom from Panama
}

Alina Uribe-Arjona ${ }^{1,3}$, Hildaura Acosta de Patiño ${ }^{2,3^{*}}$, Víctor Martínez-Cortés ${ }^{4}$, David CorreaCeballos $^{3,4}$, Abdiel Rodríguez ${ }^{5}$, Leandra Gómez-Leija ${ }^{2}$, Natalia Vega ${ }^{3}$, José María Gutiérrez ${ }^{6}$ \& Rafael Otero-Patiño ${ }^{7}$

1. Departamento de Bioquímica y Nutrición, Facultad de Medicina, Universidad de Panamá, Panamá, Ciudad Universitaria, Estafeta Universitaria, Apartado 3366, Panamá 4, Panamá; allisice@hotmail.com

2. Departamento de Farmacología, Facultad de Medicina, Universidad de Panamá, Panamá, Ciudad Universitaria, Estafeta Universitaria, Apartado 3366, Panamá 4, Panamá; eleandg@yahoo.com

3. Centro de Investigación e Información de Medicamentos y Tóxicos (CIIMET), Facultad de Medicina, Universidad de Panamá, Panamá, Ciudad Universitaria, Estafeta Universitaria, Apartado 0824-00167, Panamá, Panamá; hildaura6@gmail.com,nataliavega@usf.edu

4. Centro para Investigaciones y Respuestas en Ofidiologia (CEREO), Facultad de Ciencias Naturales, Exactas y Tecnología, Universidad de Panamá, Panamá, Ciudad Universitaria, Estafeta Universitaria, Apartado 3366, Panamá 4, Panamá; pvmartinez@gmail.com, viperidaepanama@gmail.com

5. Centro Regional Universitario de Veraguas, Universidad de Panamá, Veraguas, Panamá, Apartado 3366, Panamá 4, Panamá; aernesto@hotmail.com

6. Instituto Clodomiro Picado, Facultad de Microbiología, Universidad de Costa Rica, San José, Costa Rica; Apartado 11501 San José, Costa Rica; jose.gutierrez@ucr.ac.cr

7. Facultad de Medicina, Universidad de Antioquia, Medellín, Colombia; Calle 7 A Sur No. 35-55, Apto. 505, Medellin, Colombia; rafaotero@une.net.co

* Correspondence

Received 31-X-2019. Corrected 22-V-2020. Accepted 09-XI-2020.

\begin{abstract}
Introduction: It is estimated that 2000 snakebites occur in Panama every year, $70 \%$ of which are inflicted by Bothrops asper. Objective: To determine the biochemical and toxicologic effects and to assess the immunochemical characteristics of a reference pool of B. asper venom representative of Panama. Methods: The reference venom was prepared as a homogeneous mixture of the venoms obtained from 78 adult snakes collected in four geographic areas of Panama. Enzymatic and toxicological activities were assessed. The electrophoretic pattern was studied by SDS-PAGE. Immunoreactivity of various antivenoms was analyzed by Western blot. Results: $B$. asper reference venom has lethal, hemorrhagic, myotoxic, edema-forming, coagulant, defibrinating, proteinase and phospholipase $\mathrm{A}_{2}$ activities. SDS-PAGE showed the presence of protein bands with molecular weights ranging from 8 to $70 \mathrm{kDa}$, with the presence of predominant bands at $\approx 15 \mathrm{kDa}$ and $\approx 30$ to $66 \mathrm{kDa}$, which likely correspond to phospholipases $\mathrm{A}_{2}$ and metalloproteinases, respectively. Immunoblotting showed a high degree of recognition by various antivenoms, especially by antivenoms from Colombia and Costa Rica. Conclusions: Following recommendations by the World Health Organization, this reference venom of $B$. asper of Panama will become a useful tool for the preclinical evaluation of antivenoms distributed in this country.
\end{abstract}

Key words: snakebite; venom; toxicity; immunochemical characterization; antivenom.

Uribe-Arjona, A., Acosta de Patiño, H., Martínez-Cortés, V., Correa-Ceballos, D., Rodríguez, A., Gómez-Leija, L., Vega, N., Gutiérrez, J.M., \& Otero-Patiño, R. (2020). Toxicological, enzymatic, and immunochemical characterization of Bothrops asper (Serpentes: Viperidae) reference venom from Panama. Revista de Biología Tropical, 69(1), 127-138. DOI 10.15517/rbt.v69i1.39502 
Snakebite envenoming is a global public health problem that, despite its complexity and magnitude, has not received enough attention from health authorities, pharmaceutical companies and research agencies in all parts of the world (Gutiérrez, Williams, Fan, \& Warrel, 2010). Therefore, the World Health Organization (WHO) recently included snake bite envenoming on its list of neglected tropical diseases (Gutiérrez et al., 2017).

This environmental and occupational disease affects mainly agricultural workers in rural communities in tropical regions, afflicting almost exclusively the impoverished population (Williams et al., 2010). The victims of envenoming generally live in remote communities, far from medical facilities, thus lacking timely medical attention. Furthermore, many people die on the way to medical centers, and others mostly rely on popular medicine and, therefore, are not included in the official hospital records (Otero-Patiño, 2009).

Between 130000 and 150000 snakebite cases are recorded in the Latin American region each year, with an estimated 2300 annual deaths (Chippaux, 2006). Panama has the highest incidence of snakebites in the region, registering 54-62 cases per 100000 inhabitants (approximately 2000 bites per year). The mortality rate is estimated at 0.54/100000 inhabitants (Ministry of Health, 2011). Many affected people develop physical and psychological sequelae and permanent disability, which is estimated to exceed the number of deaths (WHO, 2010; Gutiérrez et al., 2017).

In Latin America, snakes of the genus Bothrops inflict the greatest number of accidents, and $B$. asper is the principal species responsible for envenomings in Southern Mexico, Central America, and Northern South America. In the Central American region, it is estimated that $B$. asper is responsible for approximately $50-80 \%$ of snakebites, as well as most of the deaths due to these envenomings (Otero-Patiño, 2009). Popularly, B. asper is known as "Terciopelo", "Barba amarilla", "nauyaca" or "equis". It is widely distributed in the humid lowlands of Mexico, Central
America, Venezuela, Colombia and Ecuador, living both in forests and in areas of livestock and agricultural use, which consequently increases the likelihood of contacts between snakes and workers or their homes (OteroPatiño, 2009).

The venom of $B$. asper induces both local alterations at the site of venom injection (edema, hemorrhage, dermonecrosis, flictenas, myonecrosis), and systemic effects that can be life threatening (defibrination, bleeding distant from the bite site, nephrotoxicity and cardiovascular shock) (Otero et al., 2002; Gutiérrez \& Lomonte, 2003; Gutiérrez, Escalante, \& Rucavado, 2009; Gutiérrez, Rucavado, Chaves, Díaz, \& Escalante, 2009). Snake venom is a complex mixture, which in addition to a large variety of toxins, enzymes and proteins without enzymatic activity, also contains amino acids, nucleotides, phosphorylated sugars, lipids, and metal ions. Research in proteomics has shown a high number of different proteins in the venom of B. asper (Alape-Girón et al., 2008), which predominantly belong to the families of metalloproteinases (41-44\%), phospholipases $\mathrm{A}_{2}(29-45 \%)$, serine proteinases (4-18\%), L-amino acid oxidases (5-9 \%), disintegrins (1-2 \%) and lectin-like C-type proteins (Angulo \& Lomonte, 2009).

There is significant qualitative and quantitative variation in the biochemical composition of venoms, both between and within species. These differences have their origin in ontogenetic, geographic, phylogenetic, and environmental factors, as well as individual factors (Gutiérrez, Chaves \& Bolaños, 1980; Saldarriaga et al., 2003; Núñez \& Otero, 1999; Alape-Girón et al., 2008).

Martínez (1983a; 1983b) and Quintero, González, Suárez, \& Arantes (2007) studied some biochemical and toxicological characteristics of $B$. asper venoms from Panama. A previous study described slight variations in the toxic and enzymatic activities in the venoms of pools of $B$. asper venoms from several regions in Panama, although venoms were in general similar (Vélez et al., 2017). 
Antivenoms remain the only specific and effective treatment for envenoming caused by snakebites (Gutiérrez, Williams, Fan, \& Warrell, 2010). Owing to the described variation in venom composition, antivenoms should be subjected to preclinical evaluations (neutralization of lethality and other toxic activities) against the most relevant snake venoms from a particular country or region (Otero et al., 1995; Williams et al., 2010; Gutiérrez et al., 2013). To this end, the World Health Organization (WHO) has recommended the preparation of reference national venom pools of the medically-relevant snake species and to characterize such reference venoms, in order to use them in the preclinical evaluation of antivenoms being used in the countries.

The venom of $B$. asper from various countries has been extensively studied in terms of its biochemical and toxicological characteristics (Angulo \& Lomonte, 2009; Gutiérrez, Escalante, \& Rucavado, 2009; Gutiérrez, Rucavado, Chaves, et al., 2009). However, no national reference venom of $B$. asper has been prepared and characterized in any country. The present study was carried out with the aim of characterizing the toxicological and enzymatic effects, as well as the immunochemical reactivity, of a reference venom of $B$. asper from Panama, prepared by generating a pool of venoms from four geographic regions in this country. This venom mixture can be used in the preclinical evaluations to test the efficacy of antivenoms distributed in Panama.

\section{MATERIALS AND METHODS}

Animals and venom: The venom was obtained via manual milking of 78 adult specimens of $B$. asper collected in the following four geographical regions of mainland of Panama: Zone 1: Bocas del Toro, Veraguas' Caribbean region, Colon and Guna Yala; Zone 2: Chiriquí and Veraguas' Pacific region; Zone 3: Los Santos, Herrera and Coclé; and Zone 4: Panama Oeste, Panama and Darien (Fig. 1). The snakes were kept in captivity at the Serpentarium located in the School of Biology at the University of Panama. Once collected, the crude

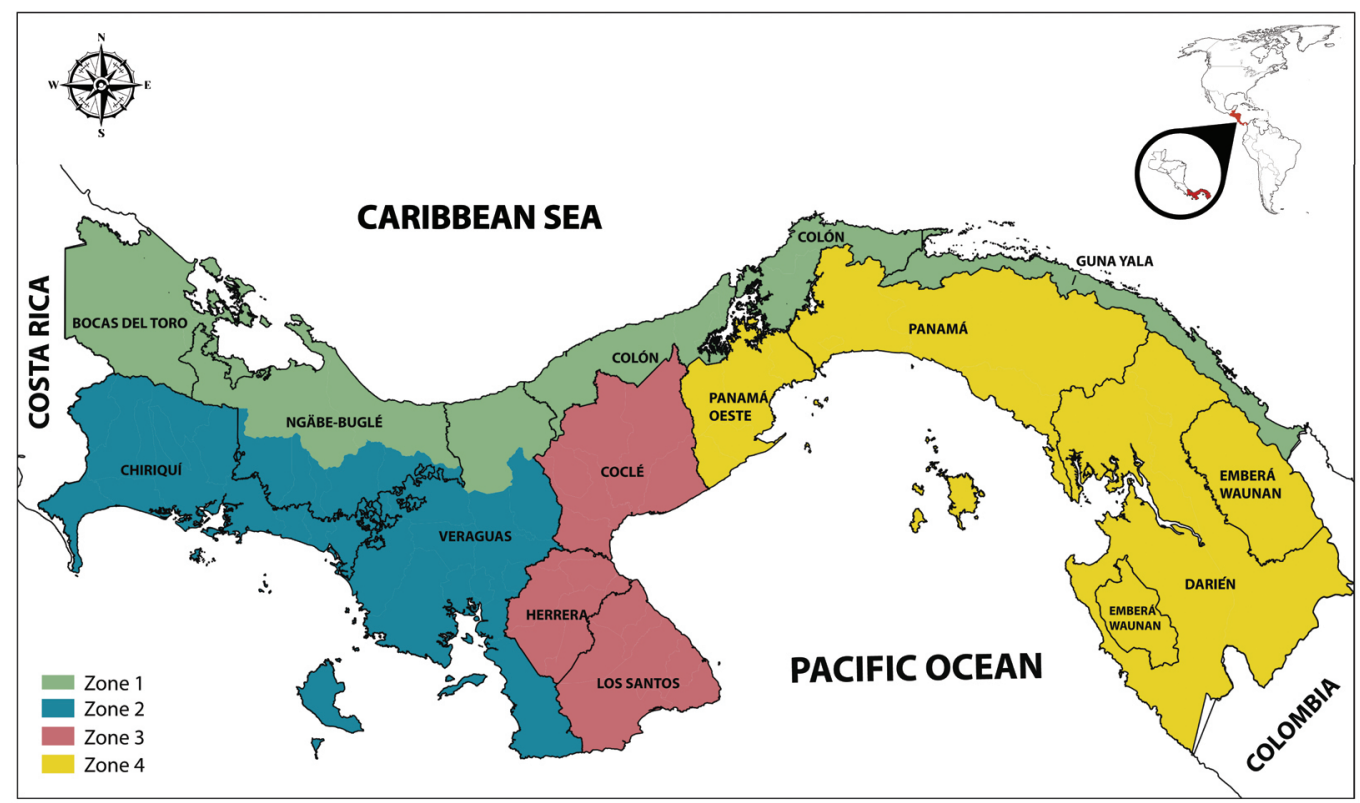

Fig. 1. Geographical regions where Bothrops asper snakes were collected. Zone 1: Bocas del Toro, Veraguas' Caribbean region, Colon and Guna Yala; Zone 2: Chiriquí and Veraguas' Pacific region; Zone 3: Los Santos, Herrera and Cocle; and Zone 4: West Panama, Panama and Darien. 
venom was centrifuged for $15 \mathrm{~min}$ at 3000 rpm. The supernatant was frozen at $-20{ }^{\circ} \mathrm{C}$, lyophilized and stored at $-20{ }^{\circ} \mathrm{C}$ until use. To ensure geographical representation, a homogeneous mixture was prepared using $100 \mathrm{mg}$ of lyophilized venom from each geographical zone in order to prepare the reference venom. Snakes used for the preparation of this reference venom were adults; $52 \%$ were females and $48 \%$ were males. Approximately half of the specimens were collected during the dry season (December to April) and the other half during the rainy season (May to November).

For the in vivo tests, mice of the strain CD-1, with a body weight of 18-20 g, were used following the recommendations of the Guide for the Care, Ethics and Use of Laboratory Animals of the National Research Council of the National Academies (2011). The mice were provided by the Bioterium at the University of Panama. When these studies were carried out, the Ethics Committee in Animal Use had not been established in our country.

\section{Venom toxicological and enzymatic effects}

Hemorrhage: Groups of four mice per dose received intradermal (i.d.) injections, in the ventral abdominal area, of a range of doses of venom (1.0-16.0 $\mu \mathrm{g})$ in a volume of $100 \mu \mathrm{l}$ of phosphate buffered saline solution (PBS) at $\mathrm{pH}$ 7.2. The control group received an equivalent volume of PBS. The animals were sacrificed $2 \mathrm{~h}$ later by inhalation of anesthetic (Sevorane ${ }^{\circledR}$ ) and the area of hemorrhage in the inner side of the skin was measured. The Minimum Hemorrhagic Dose (DHm) was the dose of venom that induced an area of hemorrhage of $10 \mathrm{~mm}$ in diameter, following the method of Kondo, Kondo, Ikesawa, Murata, \& Ohsaka, (1960), modified by Gutiérrez, Gené, Rojas, \& Cerdas (1985).

Edema-forming: Groups of four mice per dose received subcutaneous (s.c.) injections, in the right paw (subplantar), of a range of doses of venom (0.031-0.5 $\mu \mathrm{g})$, diluted in a volume of $5 \mu \mathrm{l}$ of PBS. As a control, $5 \mu \mathrm{l}$ of PBS were injected into the left paw of each mouse. After 3 $\mathrm{h}$, the relative volume (edema) of the right paw versus the left paw (control) was measured in each animal, using an LE 7500 digital plethysmometer from PanLab Harvard Apparatus. The Minimum Edema-forming Dose (DEm) was the dose of venom that caused $30 \%$ increase in paw volume at $3 \mathrm{~h}$, following the method of Yamakawa, Nozaki, \& Hokama, (1976), modified by Chaves, Barboza, \& Gutiérrez (1995).

Myotoxicity: Groups of four mice per dose were received intramuscular (i.m.) injections, in the right gastrocnemius, of a range of doses $(25$ to $50 \mu \mathrm{g})$ of $B$. asper venom in 100 $\mu \mathrm{l}$ of PBS. The control group received the same volume of PBS. After $3 \mathrm{~h}$, mice were anesthetized and blood samples were collected from the orbital venous sinus, using heparinized capillaries, to quantify the activity of the enzyme creatine kinase (CK) in the plasma, with a commercial kit (CK NAC liquiUV, Human). The Minimum Myotoxic Dose (DMm) was the dose of venom that induced a four-fold increase in plasma CK activity, compared with the control group (Gutiérrez, Arroyo, \& Bolaños, 1980). Myotoxic activity was also expressed as the CK activity of plasma from mice injected with $50 \mu \mathrm{g}$ of venom (Segura et al., 2010).

Lethality: Groups of five mice per dose received intraperitoneal (i.p.) injections of a range of doses of venom ( 1 to $7 \mathrm{mg} / \mathrm{kg}$ ), diluted in a volume of $500 \mu \mathrm{l}$ of PBS. The number of mice dead at $48 \mathrm{~h}$ was recorded. Lethal Dose $\left(\mathrm{LD}_{50}\right)$ was obtained by the Spearman-Karber method (WHO, 1981), using TOXICALC software provided by the Instituto Clodomiro Picado (University of Costa Rica).

Coagulant effect: Test tubes with $200 \mu \mathrm{l}$ of citrated platelet-free human plasma were incubated at $37^{\circ} \mathrm{C}$ with a volume of $100 \mu$ of PBS containing different amounts of venom (0.16-1.8 $\mu \mathrm{g}$ ). The clotting time was recorded in seconds. The Minimum Coagulant Dosage (DCm) was the dose of venom that induced the 
coagulation of the plasma in $60 \mathrm{~s}$ (Gené, Roy, Rojas, Gutiérrez \& Cerdas, 1989).

Defibrinating effect: Groups of four mice received intravenous (i.v.) injections, into the caudal vein, with different doses of venom $(0.625-20.0 \mu \mathrm{g})$ in a volume of $200 \mu \mathrm{l}$ of PBS. After $1 \mathrm{~h}$ the mice were anesthetized by inhalation of Sevorane ${ }^{\circledR}$ and cardiac puncture was realized to obtain whole blood samples, which were placed in glass tubes and maintained at room temperature for $1 \mathrm{~h}$. The Minimum Defibrinating Dose (DDm) was the minimum dose of venom that caused anticoagulation in all injected mice (Theakston \& Reid, 1983; Gené et al., 1989).

Proteolysis: Proteolytic activity was tested by incubating various amounts of venom in $2 \mathrm{ml}$ of casein (2\% in PBS, pH 8.0) for 30 min. The reaction was stopped by adding 4.0 $\mathrm{ml}$ of $5 \%$ trichloroacetic acid. After $5 \mathrm{~min}$, the tubes were centrifuged at $3000 \mathrm{rpm}$ for $10 \mathrm{~min}$ and the absorbances of the supernatant were recorded at $280 \mathrm{~nm}$ against the blank reagent. The Minimum Proteolytic Dose (DPm) was determined as the amount of venom that produced an absorbance change of 0.5 at $280 \mathrm{~nm}$ (Lomonte \& Gutiérrez, 1983).

Indirect Hemolysis (Phospholipase $\mathbf{A}_{2}$ Activity): The activity of phospholipase $\mathrm{A}_{2}$ was determined using agarose plates $(0.8 \%$ in PBS, $\mathrm{pH}$ 7.2) prepared with human erythrocytes, $\mathrm{CaCl}_{2}(0.01 \mathrm{M})$ and a suspension of egg yolk (1:4 in PBS). Volumes of $15 \mu \mathrm{l}$ of solution with increasing concentrations of venom $(1.2-30.0 \mu \mathrm{g})$ were applied in $3 \mathrm{~mm}$ diameter wells. Then, the plates were incubated for 20 $\mathrm{h}$ at $37^{\circ} \mathrm{C}$ and the diameter of hemolytic halos was measured. The Minimum Hemolytic Dose (DHLm) was the dose of venom that induced a hemolysis halo of $20 \mathrm{~mm}$ diameter in $20 \mathrm{~h}$ (Gutiérrez, Avila, Rojas \& Cerdas, 1988).

\section{Immunochemical characterization of the venom}

Quantification of proteins: The protein content of the venom was estimated by the Bradford method, as modified by Spector (1978), using bovine serum albumin as the standard.

Electrophoresis-SDS PAGE: Electrophoresis was performed in $15 \%$ polyacrylamide vertical minigels in the presence of sodium dodecylsulfate (SDS-PAGE) (Laemmli, 1970). For each run, $15 \mu \mathrm{g}$ of venom equivalent to 11 $\mu \mathrm{g}$ of protein were used under reducing conditions with $\beta$-mercaptoethanol, and $150 \mathrm{~V}$ were applied for 70 min in a Mini-Protean II chamber from Bio-Rad (Richmond, CA, USA). The reference venom (pool of the four regions) and venoms from each region were run in parallel with a molecular mass marker (Bio-Rad-cata$\log$ No. 161-0304). After separation, gels were stained with Coomassie Brilliant Blue. Densitometry was performed using myImageAnalysis $^{\text {TM }}$ Software from Thermo Fisher Scientific.

Preparation of anti- $B$. asper serum: Two New Zealand female rabbits (2-3 kg) were immunized using variable doses of the reference venom from Panama, ranging between 250 and $1000 \mu \mathrm{g}$, which were applied s.c. (the first two doses) and i.m. (the last dose), at monthly intervals, using appropriate adjuvants (complete and incomplete Freund's adjuvants). After 60 days, blood was collected, and the serum was separated by centrifugation and passed through protein A columns to obtain IgG (specific and non-specific against the venom). The fractions collected were dialyzed against distilled water, then lyophilized and frozen until use (Lomonte, 2002).

Immunological reactivity (Western blotting): The reference venom from Panama was separated by SDS-PAGE (as previously 
described) and transferred for $2 \mathrm{~h}$ to nitrocellulose membranes in a Mini-Transblot ${ }^{\circledR}$ chamber from Bio-Rad.

As a primary antibody, polyvalent antivenoms from different regions of Latin America were used: Argentina (Instituto Biológico Argentino Saic-lot 1604), Brazil (Instituto Vital Brazil SA, lot 095106E), Colombia (Laboratorio Probiol SA, lot Ap310ix10), Costa Rica (Instituto Clodomiro Picado, lot 4691110POLQ) and Panama (anti- $B$ asper serum produced in rabbits).

The membranes were incubated at room temperature with the corresponding antivenoms in a dilution of 1:1000 (in PBS Tween 20) for $3 \mathrm{~h}$. They were then incubated for 2 $\mathrm{h}$ at room temperature with a dilution 1:5000 of anti-horse $\mathrm{IgG}$ or anti-rabbit IgG (whole molecule)-Peroxidase antibody produced in rabbit, as a secondary antibody. Subsequently, the reaction was revealed using a solution of hydrogen peroxide in the presence of 4-Cl1-naphthol and diaminobenzidine. The reaction was stopped by adding distilled water at the time the bands appeared.

Presentation of the results: All toxicological and enzymatic tests were performed in triplicate. The results are expressed as the mean \pm S.E.M (standard error of the mean), except for lethality, in which case variability is expressed with $95 \%$ confidence intervals.

\section{RESULTS}

The reference venom of $B$. asper from Panama induced characteristic local and systemic effects of venoms of the Viperidae family. This venom possesses lethal, hemorrhagic, myotoxic, edema-forming, defibrinating and in vitro coagulant activities; it also shows proteolytic and phospholipase $\mathrm{A}_{2}$ enzymatic activities (Table 1). In addition to estimating the Minimum Myotoxic Dose, creatine kinase (CK) activity $3 \mathrm{~h}$ after the intramuscular injection of $50 \mu \mathrm{g}$ of venom corresponded to $10196 \pm 1817 \mathrm{U} / \mathrm{l}$.

When venom protein components were separated by SDS-PAGE (Fig. 2), fractions with molecular weights between 8 and $70 \mathrm{kDa}$ were observed, with the presence of predominant bands at $70 \mathrm{kDa}, 42-48 \mathrm{kDa}, 24-37 \mathrm{kDa}$, $15 \mathrm{kDa}$ and $11 \mathrm{kDa}$. The percent composition of the main protein fractions in Panamanian reference venom can be seen in Table 2 .

Fig. 3A shows the SDS-PAGE profile of the proteins of $B$. asper reference venom from Panama. Western blot analysis of the immunological reactivity of several Latin American

TABLE 1

Toxicological and enzymatic activities of the reference venom of Panamanian Bothrops asper

\begin{tabular}{lc}
\multicolumn{1}{c}{ Test } & Results \pm S.E.M. \\
Hemorrhagic activity (DHm) & $4.93 \pm 0.29 \mu \mathrm{g}$ \\
Myotoxic activity (DMm) & $10.2 \pm 1.68 \mu \mathrm{g}$ \\
Edema-forming activity (DEm) & $0.32 \pm 0.04 \mu \mathrm{g}$ \\
Coagulant activity (DCm) & $0.53 \pm 0.04 \mu \mathrm{g}$ \\
Defibrinating activity (DDm) & $1.25 \pm 0.0 \mu \mathrm{g}$ \\
Proteolytic activity (DPm) & $1.39 \pm 0.1 \mathrm{mg}$ \\
Phospholipase $\mathrm{A}_{2}$ activity (DHIm) & $2.93 \pm 0.3 \mu \mathrm{g}$ \\
Lethal activity $\left(\mathrm{DL}_{50}\right)$ & $4.84 \mathrm{mg} / \mathrm{kg}(3.98-5.88)$
\end{tabular}

DHm: Minimum Hemorrhagic Dose; DMm: Minimum Myotoxic Dose; DEm: Minimum Edema-forming Dose; DCm: Minimum Coagulant Dose; DDm: Minimum Defibrinating Dose; DPm: Minimum Proteolytic Dose; DHlm: Minimum Indirect Hemolytic Dose (Phospholipase Activity A2); $\mathrm{DL}_{50}$ : Medium Lethal Dose. The $95 \%$ confidence intervals are shown in parentheses. S.E.M.: Standard Error of the Mean. The definitions of each dose are detailed in the Materials and Methods section. 


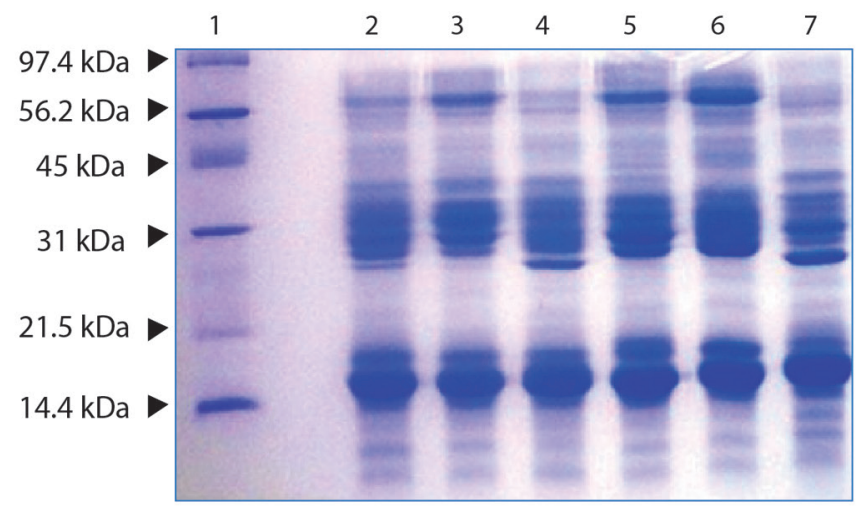

Fig. 2. Electrophoretic patterns obtained by SDS PAGE (15\% acrylamide) run under reducing conditions using $15 \mu \mathrm{g}$ of Panamanian B. asper reference venom, Costa Rican venom and venom from each Panamanian zone. Lane 1: Low Range Molecular Weight Marker (Bio-Rad); Lane 2: Reference B. asper venom from Panama; Lane 3: B. asper venom from Costa Rica; Lane 4: B. asper venom from Panama Zone 1 (Atlantic); Lane 5: B. asper venom from Panama Zone 2 (Chiriquí and Pacific Veraguas); Lane 6: B. asper venom from Panama Zone 3 (Los Santos, Herrera and Cocle); Lane 7: B. asper venom from Panama Zone 4 (Panama and Darién). Gels were stained with Coomassie Brilliant Blue.

TABLE 2

Percent composition of the protein fractions of Bothrops asper venom from Panama

\begin{tabular}{cc} 
Molecular Weight (kDa) & Content (Average percent) \\
$55-70$ & 7.1 \\
$42-48$ & 8.3 \\
$24-37$ & 37.4 \\
15 & 40.0 \\
11 & 7.2 \\
\hline
\end{tabular}

Determined by densitometry using My Image Analysis ${ }^{\mathrm{TM}}$ software (Thermo Scientific).

antivenoms against the reference venom of $B$. asper from Panama is shown in Fig 3B. All antivenoms reacted against most of the bands, but a higher reactivity was observed for the antivenoms of Costa Rica and Colombia.

All antivenoms showed immunorecognition for protein bands of 15-16 kDa and 25-30 $\mathrm{kDa}$, the former bands containing $\mathrm{PLA}_{2}$, such as myotoxins, and the latter bands containing metalloproteinases PI, serine proteinases and PLA $_{2}$. Fractions of proteins with masses between 42-48 $\mathrm{kDa}$ and 55-70 kDa were highly recognized by all antivenoms. All antivenoms, but particularly those from Costa Rica and Colombia, presented immunoreactivity against the $11 \mathrm{kDa}$ fraction.

\section{DISCUSSION}

This study follows the recommendation of the WHO Guidelines for the Production, Control and Regulation of Snake Antivenom Immunoglobulins (WHO, 2010) in the sense that it is relevant to prepare national reference snake venoms of the species of highest medical impact. Few countries, such as Brazil, have prepared reference venoms (Araújo et al., 2017). In our study, a reference venom of $B$. asper from Panama has been prepared, including representative venom samples from adult specimens collected in the various regions of this country. This venom has been characterized in terms of its toxicological and enzymatic activities, as well as its electrophoretic pattern in SDS-PAGE. This national reference venom can be used in the preclinical assessment of the neutralizing efficacy of antivenoms distributed in this Central American country. The reference venom from Panamanian B. asper was found to induce lethal, edema-forming, coagulant, hemorrhagic and myotoxic activities. Therefore, this toxicological profile is similar to the one previously described for $B$. asper venoms from other Central American countries and from Mexico (Gutiérrez, Chaves \& Bolaños, 1980; 

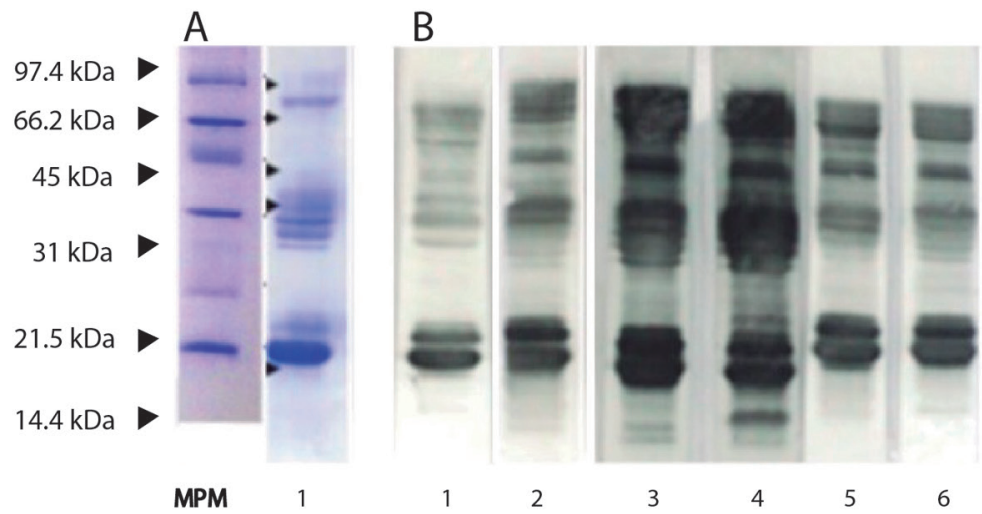

Fig. 3. Electrophoresis and Western blotting assays. A. SDS PAGE electrophoresis of $B$. asper reference venom from Panama. MPM: Low Range molecular marker (Bio-Rad); 1. Panamanian B. asper reference venom (15 $\mu \mathrm{g}$ of lyophilized venom) separated by SDS PAGE (15\%) under reducing conditions; B. Immunological reactivity against $B$. asper reference venom from Panama determined by Western blotting using antivenoms produced in Latin America. 1. Antivenom anti $B$. asper from Panama (produced in rabbits); 2. Antivenom from Venezuela; 3. Antivenom from Costa Rica; 4. Antivenom from Colombia; 5. Antivenom from Brazil; 6. Antivenom from Argentina.

Saravia et al., 2001; Quintero et al., 2007; Segura et al., 2010).

The most important parameter of toxicity of a venom is the Median Lethal Dose $\left(\mathrm{LD}_{50}\right)$. The Panamanian B. asper reference venom had an $\mathrm{LD}_{50}$ of $91.9 \mu \mathrm{g}$ ( 95 confidence limits: 75.6$111.7 \mu \mathrm{g})$, which corresponds to a dose of 4.84 $\mathrm{mg} / \mathrm{kg}$ (95\% confidence limits: 3.98-5.88 mg). This value is similar to the results obtained for adult $B$. asper venoms from other regions in Latin America, as published by Gutiérrez, Chaves \& Bolaños (1980), Otero et al. (1995), Saravia et al. (2001), Gutiérrez, Escalante, \& Rucavado (2009) and Segura et al. (2010).

This reference venom from Panama showed high edematigenous and myotoxic activities. Hemorrhagic effect was also observed with this Panamanian reference venom, with a DHm value of $4.93 \pm 0.29 \mu \mathrm{g}$. The venoms from specific regions of Panama, studied by Martínez (1983b) and Quintero et al. (2007), presented values of $2.5 \mu \mathrm{g}$ and $6.3 \pm 3.6 \mu \mathrm{g}$, respectively. It should be taken into account that the reference venom contains snake venoms from all regions of Panama (including the regions studied by these authors), which could explain the intermediate value of the $\mathrm{DHm}$ found in this study.
With regards to in vitro coagulant activity, the Panama reference venom had a DCm of $0.536 \pm 0.040 \mu \mathrm{g}$, which is slightly higher than the reported value for Costa Rican venom $(\mathrm{DCm}=0.32 \pm 0.02 \mu \mathrm{g})$ (Segura et al., 2010) and lower than for Guatemalan venom (3.9 \pm $0.08 \mu \mathrm{g}$; Saravia et al., 2001). The defibrinating action in vivo of the Panama reference venom was evaluated through the DDm, which was $1.25 \mu \mathrm{g} /$ mouse. This value is similar to the Colombian venom $(\mathrm{DDm}=1.1 \pm 0.3 \mu \mathrm{g})$ (Otero et al., 1995). However, it appears to be more active than its Costa Rican counterpart $(\mathrm{DDm}=3.0 \pm 0.5 \mu \mathrm{g}$ ) (Segura et al., 2010).

The proteolytic activity of viperid venoms is associated with coagulopathies, edema, local tissue damage and hemorrhage. The value of the DPm for the Panamanian reference venom was $1.39 \pm 0.1 \mathrm{mg}$. This is similar to those previously reported for the venoms of $B$. asper of the Atlantic and Pacific regions of Costa Rica, which have values of $\mathrm{DPm}=1.2$ and $1.4 \mathrm{mg}$, respectively (Gutiérrez at al., 1985) and slightly higher than that of the $B$. asper venom from Honduras $(\mathrm{DPm}=2.1 \mathrm{mg}$ ) (Rojas et al, 1987).

The reference Panama venom showed indirect hemolytic activity (induced by phospholipases $A_{2}$ ), with a DHlm of $2.93 \pm 0.3 \mu \mathrm{g}$. 
This value is similar to that obtained with $B$. asper venoms from Antioquia-Chocó (DHlm $=$ $2.0 \mu \mathrm{g}$ ) in Colombia (Otero et al., 1995).

Electrophoretic analysis by SDS-PAGE of the reference venom and of venoms from the different regions of Panama showed qualitatively similar patterns, although quantitative differences were observed, through densitometric analysis, in the percentages of each one of the electrophoretic bands. Previous work analyzed the variation of $B$. asper venoms from these populations in Panama and showed that, both in their toxic and electrophoretic profiles, these venoms were similar (Velez et al., 2017). However, the small variations found in electrophoretic patterns among the populations highlights the need for including representative samples of snakes from the various regions in Panama, in order to have a truly representative national reference venom preparation.

As for Western blot, the similar patterns of immunorecognition observed between the different antivenoms could be attributed to two aspects: the cross-reactivity and the similarities that exist between the proteins of the venoms of the same genus and species, even if they are from different countries. The high reactivity of the antivenoms of Costa Rica and Colombia may be related to the close similarity in the composition of the $B$. asper venoms of these countries and their immunological similarities. Both antivenoms include $B$. asper venom in their antigenic mixture, which explains the high degree of recognition. The experimental monospecific serum obtained from rabbits immunized with Panamanian $B$. asper venom did not show such strong immunorecognition. This might be due to the fact that commercial antivenoms produced in horses subjected to cycles of repeated immunizations show greater neutralization than experimental antivenoms produced in a single round of immunization (Gutiérrez et al., 2010).

These immunochemical results suggest that the antivenoms tested in this study could be effective in neutralizing the main effects inflicted by the toxins of the venom. However, the preclinical efficacy of antivenoms should be assessed by studying the neutralization of toxic and enzymatic activities of this reference venom, since immunoreactivity by ELISA or Western blot does not necessarily imply neutralization of toxicity (Gutiérrez et al., 2010). For this reason, immunochemical tests, such as Western blotting, should not be used as a basis to recommend the therapeutic use of a specific antivenom (Otero-Patiño, 2009), although they are useful to determine immunological similarities between venoms.

In conclusion, this study described the preparation of a national reference venom of $B$. asper from Panama, prepared by pooling venom samples from specimens collected in various regions of the country. It is therefore a representative venom from this country. The toxicological, enzymatic, and electrophoretic characterization of this reference venom underscores strong similarities with venoms from this species collected in other countries. In the light of the recommendations of the World Health Organization (WHO), this national reference venom will be useful for assessing the preclinical efficacy of antivenoms distributed in this Central American country.

Ethical statement: authors declare that they all agree with this publication and made significant contributions; that there is no conflict of interest of any kind; and that we followed all pertinent ethical and legal procedures and requirements. All financial sources are fully and clearly stated in the acknowledgements section. A signed document has been filed in the journal archives.

\section{ACKNOWLEDGMENTS}

This study received financial support from the School of Medicine, School of Veterinary Medicine, Regional University Center of Veraguas and the Vice-rectorate of Research and Postgraduate Studies of the University of Panama, SENACYT (COL06-017; EST09087 B; INF10-051), and Institute Clodomiro Picado, University of Costa Rica. We want to thank to Department of Biochemistry and 
Nutrition and the Department of Pharmacology of the School of Medicine of the University of Panama. To Jackeline Morán, Hermes Fuentes, Marcos Salazar and Adolfo Castillo for the support provided. And our gratitude to Tomás Diez and Juan Miguel Pascale for their scientific and technical advice.

\section{RESUMEN}

Caracterización toxicológica, enzimática e inmunoquímica del veneno de referencia de Bothrops asper (Serpentes: Viperidae) de Panamá. Introducción: Se estima que 2000 mordeduras de serpiente ocurren en Panamá cada año, el $70 \%$ de las cuales son infligidas por Bothrops asper. Objetivo: Determinar los efectos bioquímicos y toxicológicos y evaluar las características inmunoquímicas del veneno de referencia de $B$. asper representativo de Panamá. Métodos: El veneno de referencia se preparó como una mezcla homogénea de los venenos obtenidos de 78 serpientes adultas recolectadas en cuatro áreas geográficas de Panamá. Se evaluaron las actividades enzimáticas y toxicológicas. El patrón electroforético se estudió mediante SDS-PAGE. La inmunoreactividad de varios antivenenos se analizó mediante transferencia de Western. Resultados: El veneno de referencia de B. asper tiene actividades letales, hemorrágicas, miotóxicas, formadoras de edema, coagulantes, desfibrinante, proteolítica y de fosfolipasa $A_{2}$. El análisis de SDS-PAGE mostró la presencia de bandas de proteínas con pesos moleculares que varían de 8 a $70 \mathrm{kDa}$, con la presencia de bandas predominantes a $\approx 15 \mathrm{kDa} \mathrm{y} \approx 30$ a $66 \mathrm{kDa}$, que probablemente corresponden a fosfolipasas A2 y metaloproteinasas, respectivamente. La inmunotransferencia mostró un alto grado de reconocimiento por varios antivenenos, especialmente por antivenenos de Colombia y de Costa Rica. Conclusiones: Siguiendo las recomendaciones de la Organización Mundial de la Salud, este veneno de referencia de $B$. asper de Panamá se convertirá en una herramienta útil para la evaluación preclínica de antivenenos distribuidos en este país.

Palabras clave: mordedura de serpiente; veneno; toxicidad; caracterización inmunoquímica; antiveneno.

\section{REFERENCES}

Alape-Girón, A., Sanz, L., Escolano, J., Flores-Díaz, M., Madrigal, M., Sasa, M., \& Calvete, J.J. (2008). Snake Venomics of the Lancehead Pitviper Bothrops asper: Geographic, Individual, and Ontogenetic Variations. Journal of Proteome Research, 7(8), 3556-3571.
Angulo, Y., \& Lomonte, B. (2009). Biochemistry and toxicology of toxins purified from the venom of the snake Bothrops asper. Toxicon, 54, 949-957.

Araújo, H.P., Lucas, E.P.R., Moura W.C., Fátima Barbosa, C., Rodrigues, R.J., Morais, J.F., ... Boller, M.A.A. (2017). Interlaboratory study for the establishment of Brazilian Bothrops reference venom and antivenom for potency evaluation of Bothrops antivenom. Biologicals, 49, 1-5.

Chaves, F., Barboza, M., \& Gutiérrez, J.M. (1995). Pharmacological study of edema induced by venom of the snake Bothrops asper (Terciopelo) in mice. Toxicon, 33, 31-39.

Chippaux, J.P. (2006). Snake Venoms and Envenomations. Florida, USA: Krieger Publishing Company.

Gené, J.A., Roy, A., Rojas, G., Gutiérrez, J.M., \& Cerdas, L. (1989). Comparative study on the coagulant, defibrinating, fibrinolytic and fibrinogenolytic activities of Costa Rican Crotaline snake venoms and their neutralization by a polyvalent antivenom. Toxicon, 27, 841-848.

Gutiérrez, J.M., Chaves, F., \& Bolaños, R. (1980). Estudio comparativo de venenos de ejemplares recién nacidos y adultos de Bothrops asper. Revista de Biología Tropical, 28, 341-351.

Gutiérrez, J.M., Arroyo, O., \& Bolaños, R. (1980). Mionecrosis, hemorragia y edema inducidos por el veneno de Bothrops asper en ratón blanco. Toxicon, 18, 603-610.

Gutiérrez, J.M., Gené, J.A., Rojas, G., \& Cerdas, L. (1985). Neutralization of proteolytic and hemorrhagic activities of Costa Rican snake venoms by a polyvalent antivenom. Toxicon, 23, 887-893.

Gutiérrez, J.M., Avila, C., Rojas, E., \& Cerdas, L. (1988). An alternative in vitro method for testing the potency of the polyvalent antivenom produced in Costa Rica. Toxicon, 26(4), 411-413.

Gutiérrez, J.M., \& Lomonte, B. (2003). Efectos locales en el Envenenamiento ofídico en América Latina. In J.L.C. Cardoso, F.O.S. França, H.W. Fan, C.M.S.A. Málaque, V. Hadad Jr. (Eds.), Animais Peçonhentos no Brasil. Biología, Clínica e Terapéutica dos Acidentes (pp. 310-323). Sao Paulo, Barzil: Sarvier/ FAPESP.

Gutiérrez, J.M., Escalante, T., \& Rucavado, A. (2009). Experimental pathophysiology of systemic alterations induced by Bothrops asper snake venom. Toxicon, 54, 976-987.

Gutiérrez, J.M., Rucavado, A., Chaves, F., Díaz, C., \& Escalante, T. (2009). Experimental Pathology of Local Tissue Damage induced by Bothrops asper snake venom. Toxicon, 54, 958-975. 
Gutiérrez, J.M., Williams, D., Fan, H.W., \& Warrell, D.A. (2010). Snakebite Envenoming From A Global Perspective: Towards An Integrated Approach. Toxicon, 56(7), 1223-1235.

Gutiérrez, J.M., Sanz, L., Flores-Díaz, M., Figueroa, L., Madrigal, M., Herrera, M., ... Calvete, J. (2010). Impact of regional variation in Bothrops asper snake venom on the design of antivenoms: integrating antivenomics and neutralization. Journal of Proteome Research, 9, 564-577.

Gutiérrez, J.M., Solano, G., Pla, D., Herrera, M., Segura, Á., Villalta, M., ... León, G. (2013). Assessing the preclinical efficacy of antivenoms: from the lethality neutralization assay to antivenomics. Toxicon, 69 , 168-179.

Gutiérrez, J.M., Calvete, J.J., Habib, A.G., Harrison, R.A., Williams, D.J., \& Warrell, D.A. (2017). Snakebite envenoming. Nature Reviews Disease Primers, 3(September), 17063.

Kondo, H., Kondo, S., Ikesawa, H., Murata, R., \& Ohsaka, A. (1960). Studies on the quantitative method for determination of hemorrhagic activity A. of habu snake venom. Japanese Journal of Medical Science and Biology, 13, 43-51.

Laemmli, U.K. (1970). Cleavage of structural proteins during the assembly of the head of Bacteriophage T4. Nature, 227, 680-685.

Lomonte, B., \& Gutiérrez, J.M. (1983). Proteolytic activity of snake venoms of Costa Rica on casein. Revista de Biología Tropical, 31(1), 37-40.

Lomonte, B. (2002). Inmunología General. Manual de Laboratorio. San José, Costa Rica: Editorial Universidad de Costa Rica.

Martínez, V. (1983a). Características Toxinológicas del veneno de la serpiente Bothrops asper (Garman) de Panamá. Revista Conciencia, 1(10), 11-13.

Martínez, V. (1983b). Fer-De-Lance, "X", Terciopelo: Bothrops asper (Garman) de Panamá, algunas características biomédicas de su veneno. Revista Conciencia, 2(10), 43-46.

Ministry of Health. (2011). Mordedura de ofidio por región de salud años 2003-2009. Panama City, Republic of Panama: Epidemiology Departament.

National Research Council of the National Academies. (2011). Guide for the Care and Use of Laboratory Animals. Washington D.C., USA: The National Academies Press.

Núñez, V., \& Otero, R. (1999). Resistencia natural a los venenos de serpientes. Medunab, 2, 61-65.

Otero, R., Núñez, V., Osorio, R.G., Gutiérrez, J.M., Giraldo, C.A., \& Posada, L.E. (1995). Ability of six Latin
American antivenoms to neutralize the venom of mapana equis (Bothrops atrox) from Antioquia and Choco (Colombia). Toxicon, 33, 809-815.

Otero, R., Gutiérrez, J.M., Mesa, M.B., Duque, E., Rodríguez, O., Arango, J.L., ... Díaz, A. (2002). Complications of Bothrops, Porthidium, and Bothriechis snakebites in Colombia. A clinical and epidemiological study of 39 cases attended in a university hospital. Toxicon, 40, 1107-1114.

Otero-Patiño, R. (2009). Epidemiological, clinical and therapeutic aspects of Bothrops asper bites. Toxicon, 54, 998-1011.

Quintero, A., González, I., Soares, A.M., \& Arantes, E.C. (2007). The Venom of Bothrops asper from Panamá: Biochemical Characterization and Toxic Activities. Journal of Venomous Animals and Toxins including Tropical Diseases, 13(1), 316.

Rojas, G., Gutiérrez, J.M., Gené, J., Gómez, M., \& Cerdas, L. (1987). Neutralización de las actividades tóxicas y enzimáticas de cuatro venenos de serpientes de Guatemala y Honduras por el antiveneno polivalente producido en Costa Rica. Revista de Biología Tropical, 35(1), 59-67.

Saldarriaga, M.M., Otero, R., Núñez, V., Toro, M.F., Díaz, A., \& Gutiérrez, J.M. (2003). Ontogenetic variability of Bothrops atrox and Bothrops asper snake venoms from Colombia. Toxicon, 42(4), 405-411.

Saravia, P., Rojas, E., Escalante, T., Arce, V., Chaves, E., Velásquez, R., ... Gutiérrez, J.M. (2001). The venom of Bothrops asper from Guatemala: toxic activities and neutralization by antivenoms. Toxicon, 39(2-3), 401-405.

Segura, A., Castillo, M., Núñez, V., Yarlequé, A., Gonçalves, L., Villalta, M., ... Gutiérrez, J.M. (2010). Preclinical assessment of the neutralizing capacity of antivenoms produced in six Latin American countries against medically relevant Bothrops snake venoms. Toxicon, 56, 980-989.

Spector, T. (1978). Refinement of the Coomassie blue method of protein quantitation. A simple and linear spectrophotometric assay for less than or equal to 0.5 to 50 micrograms of protein. Analytical Biochemistry, 86(1), 142-146.

Theakston, R.D.G., \& Reid, H.A. (1983). Development of simple standard assay procedures for the characterization of snake venoms. Bulletin of World Health Organization, 61, 949-956.

Vélez, S., Salazar, M., Acosta de Patiño, H., Gómez, L., Rodríguez, A., Correa, D., ... Gutiérrez, J.M. (2017). Geographical variability of the venoms of four populations of Bothrops asper from Panama: Toxicological analysis and neutralization by a polyvalent antivenom. Toxicon, 132, 55-61. 
World Health Organization. (1981). Progress in the characterization of venoms and standardization of antivenoms. Who Offset Publication, 58, 1-44.

World Health Organization. (2010). Who Guidelines for the Production, Control and Regulation of Snake Antivenom Inmunoglobulins. Retrieved from https://www. who.int/bloodproducts/AntivenomGLrevWHO TRS_1004_web_Annex_5.pdf?ua=1
Williams, D., Gutiérrez, J.M., Harrison, R., Warrell, D., White, J., Winkel, K., \& Gopalakrishnakone, P. (2010). The Global Snake Bite Initiative: an antidote for snake bite. The Lancet, 375(2), 89-91.

Yamakawa, M., Nozaki, M., \& Hokama, Z. (1976). Fractionation of Sakishima Habu (Trimeresurus Elegans) venom and lethal, hemorrhagic, and edema-forming activities of the fractions. In A. Ohsaka, K. Hayashi, \& Y. Sawai (Eds.), Animal, Plant and Microbial Toxins (Vol. 1, pp. 97-109). New York, USA: Plenum Press. 